\title{
Puff Dosing Unit
}

National Cancer Institute

\section{Source}

National Cancer Institute. Puff Dosing Unit. NCI Thesaurus. Code C65060.

A dosing unit equal to the amount of active ing redient(s) contained in a puff. 